\title{
Effect of oven - heat and boiling on the germination and seedling development of Dichrostachys cinerea $(\mathrm{L})$ Wight and Arn (Fabaceae)
}

\author{
Macdonald Idu ${ }^{\mathrm{a} *}$, Asotie Conrad Omonhinmin ${ }^{\mathrm{b}}$ \\ Department of Botany, University of Benin, Benin City, Nigeria \\ University of Benin Department of Botany, P.MB, 1154, Benin City, Nigeria
}

(Received 24 February 1999; accepted 31 August 1999)

\begin{abstract}
Dichrostachys cinerea (L.) Wight and Arn. seeds were heated to various temperature ranges in the oven and immersed in boiling water to improve germination and determine the effect of the different pre-treatments on germination and vigour growth of the resultant seedlings. Immersing seeds in boiling water $\left(100^{\circ} \mathrm{C}\right)$ for $10 \mathrm{~s}$ recorded the highest germination percentage and energy $(94 \% ; 85 \%)$. Treatment for $40 \mathrm{~s}$ also gave good results. Incubating seeds in oven at $80^{\circ} \mathrm{C}$ for $360 \mathrm{~min}$ recorded high germination percentage $(84 \%)$ and germination energy $(70 \%)$, seeds heated at $80^{\circ} \mathrm{C}$ for $60 \mathrm{~min}$ and at $100^{\circ} \mathrm{C}$ for $360 \mathrm{~min}$ gave encouraging results. Majority of the seeds germinated within the first nine days, and subsequent seedlings from this pre-treatment were mostly of the high vigour category. (C) 1999 Inra/Éditions scientifiques et médicales Elsevier SAS
\end{abstract}

Dichrostachys cinerea / germination / seedling development / oven-heat / boiling

Résumé - Effet de la température et du trempage dans l'eau bouillante sur la germination et le développement des plantules de Dichrostachys cinerea (L.) Wight et Arn. Les graines de Dichrostachys cinerea (L.) Wigth et Arn. ont été chauffées à l'étuve à différentes températures ou trempées dans l'eau bouillante afin d'améliorer la germination et de déterminer l'action de ces différents traitements sur la germination et la croissance de la plantule. Les graines trempées dans l'eau bouillante $\left(100^{\circ} \mathrm{C}\right)$ pendant 10 secondes ont montré le plus fort pourcentage de germination et la meilleure énergie de germination $(94 \% ; 85 \%$ ). Le trempage dans l'eau bouillante pendant 40 secondes donna aussi un bon résultant. L'incubation des graines à l'étuve à $80^{\circ} \mathrm{C}$ pendant $360 \mathrm{~min}$ montra un pourcentage élevé de germination $(84 \%)$ et d'énergie de germination $(70 \%)$. Des graines chauffées à $80^{\circ} \mathrm{C}$ pendant 60 min et à $100^{\circ} \mathrm{C}$ pendant 360 min donnèrent des résultants encourageants. La plupart des graines ont germé pendant les neuf premiers jours et les plantules issues de ces germinations ont montré une forte énergie de germination. (C) 1999 Inra/Éditions scientifiques et médicales Elsevier SAS

Dichrostachys cinerea / germination / dévelopement des plantations / température / eau bouillante

Communicated by Gérard Guyot (Avignon, France)

* Correspondence and reprints

mcdonald@uniben.nigol.net.ng 


\section{Introduction}

Dichrostachys cinerea (L.) Wight and Arn. subsp. africana Brenan and Brummitt (Fabaceae) belongs to a small genus of the sub-family Mimosoideae. It is wide spread in the tropical savannah region of Africa. It is, however, the only known member of the genus in Nigeria [10]. This multi-purpose and indigenous, but under-exploited, tree species is well known for its fodder, tanning and fuel uses, as well as its soil stabilisation ability in the area where it grows. Its prospective use as an ornamental plant for urban beautification schemes is also high.

Dormancy breakage and germination improvements by heating and boiling treatments have been reported for a large number of seeds with hard coat $[3,4,5,6,7,9]$. Boiling probably stands out as one of the most extensively and successfully employed methods of terminating hard-coat seededness, particularly for seeds of members of the family Fabaceae $[9,13]$. To overcome poor germination and achieve maximum nursery recovery in seeds of a lesser-known species, such as $D$. cinerea, a specialised nursery technique, rather than a generalised method is more suitable [12]. However, such pre-treatments can be fully categorised only after its effect on germination, vigour and development of raised seedlings has been assessed. This study is part of an ongoing research into the effect of various pre-treatments on germination, germination vigour and seedling development (performance) of Dichrostachys cinerea.

\section{Materials and methods}

\subsection{Source of seed and collection method}

Seeds for the study were collected from Gieri, Adamawa State in the Sudan savanna vegetation belt $\left(12^{\circ}, 20 \mathrm{E} ; 90^{\circ}, 14 \mathrm{~N}\right)$, Nigeria. Rip pods were collected, seeds were removed and stored at ambient temperature $\left(28 \pm 3{ }^{\circ} \mathrm{C}\right)$ during the experimental period.

\subsection{Pre-treatments}

Seeds were surfaced sterilised by stirring in $0.1 \%$ mercuric chloride for $1 \mathrm{~min}$ and rinsed thoroughly thereafter in several changes of distilled water. Heat and boiling pre-treatment techniques are as outlined by $[6,9]$.

\subsubsection{Oven heat}

The effect of heating was monitored by incubating seeds in the oven at $40,60,80$ and $100{ }^{\circ} \mathrm{C}$ for 30,60 , 180,360 and $720 \mathrm{~min}$. Heated seeds were allowed to cool to ambient temperature before being planted for germination.

\subsubsection{Boiling}

Seeds were immersed in boiling water $\left(100{ }^{\circ} \mathrm{C}\right)$ for $10,4060,300$ and $900 \mathrm{~s}$. Treated seeds were immediately transferred to cold water.

\subsection{Germination}

A set of untreated seeds served as control for both the oven-heat and boiling pre-treatments. The treated and untreated seeds (control) were allowed to imbibe distilled water in glass Petri dishes lined with filter paper, following a randomised design of five replicates of 20 seeds each for the different pre-treatment under the prescribed exposure time. Germination was recorded daily for 30 days. A radicle length of $3 \mathrm{~mm}$ served as criterion for germination. The whole experimental set-up was allowed to stand under continuous fluorescent light at bench level. After germination, seedlings were transplanted at a planting depth of $2 \mathrm{~cm}$ into segmented wooden trays measuring $240 \times 120 \times 30 \mathrm{~cm}$ each and filled with sterile soil $(\mathrm{pH}=6.90)$. Each segment represented the different pre-treatment. Watering was done daily with Harris culture medium. Transplanting was carried out at a three-day interval following a completely randomised design. The height of the seedlings was measured before transplanting.

\subsection{Seedling development}

The height of transplanted seedlings was recorded at 3 -days interval. Seedlings were grouped into vigour categories based on germination and seedling height. The vigour index of Germination Vigour was estimated by calculating the germination energy-maximum daily germination [14]. The experiment lasted for 14 weeks after germination ( 30 days). 


\section{Results}

\subsection{Germination}

\subsubsection{Oven heat pre-treatment}

Table I shows the germination percentages after 30 days, germination energies at eight days and vigour categories of oven-heat treated seeds. Seeds incubated at $80{ }^{\circ} \mathrm{C}$ for $360 \mathrm{~min}$ recorded the highest germination percentage ( $84 \%$ ) obtained for the oven heat pre-treatment. Similarly heating seeds at $80{ }^{\circ} \mathrm{C}$ for $60 \mathrm{~min}$ and at $100{ }^{\circ} \mathrm{C}$ for $360 \mathrm{~min}$ gave good results $(75,55 \%)$. Poor germination was recorded for temperatures below and above $80^{\circ} \mathrm{C}$.

High germination energies were obtained for seeds heated at $80{ }^{\circ} \mathrm{C}$ for 30,60 and $360 \mathrm{~min}$ and at $100^{\circ} \mathrm{C}$ for 360 and $720 \mathrm{~min}$. The majority of the seeds germinated within the first nine days. Other heat pre-treatments showed lower energies.

\subsubsection{Boiling $\left(100^{\circ} \mathrm{C}\right)$ pre-treatment}

Immersion of seeds in boiling water $\left(100{ }^{\circ} \mathrm{C}\right)$ for $10 \mathrm{~s}$ recorded the highest germination percentage of $94 \%$ (table III). The 40-s treatment also recorded high germination percentage ( $88 \%)$. Other boiling pre-treatments recorded lower germination. Higher germination energies of 85 and $65 \%$ were recorded for 10 and 40 -s boiling treated seeds than for other boiling treatments (table III). Most of the seeds in the high-energy category germinated before the first eight days.

\subsection{Height of seedling}

Analysis of variance for a complete randomised design was carried out on the height data for seedlings grown from the oven heat and boiling pre-treated seeds to test for the effect of the two pre-treatments. The oven-heat pre-treatment was

Table I. Percentage of germination after 30 days, germination energies after eight days period and vigour categories based on germination height after 30 days for oven - heat pre-treatment.

\begin{tabular}{|c|c|c|c|c|c|}
\hline \multicolumn{2}{|c|}{ Pre-treatment } & \multirow{2}{*}{$\frac{\% \text { Germ. }}{08}$} & \multirow{2}{*}{$\frac{\text { Germ En. }}{03}$} & \multirow{2}{*}{$\frac{\mathrm{HV}}{02}$} & \multirow{2}{*}{$\frac{\mathrm{LV}}{06}$} \\
\hline $40^{\circ} \mathrm{C}$ & $30 \mathrm{~min}$ & & & & \\
\hline $40^{\circ} \mathrm{C}$ & $60 \mathrm{~min}$ & 10 & 04 & 07 & 03 \\
\hline $40^{\circ} \mathrm{C}$ & $180 \mathrm{~min}$ & 15 & 05 & 10 & 05 \\
\hline $40^{\circ} \mathrm{C}$ & $360 \mathrm{~min}$ & 18 & 05 & 10 & 08 \\
\hline $40^{\circ} \mathrm{C}$ & $720 \mathrm{~min}$ & 10 & 06 & 02 & 08 \\
\hline $60^{\circ} \mathrm{C}$ & $30 \mathrm{~min}$ & 10 & 04 & 04 & 06 \\
\hline $60^{\circ} \mathrm{C}$ & $60 \mathrm{~min}$ & 13 & 08 & 08 & 05 \\
\hline $60^{\circ} \mathrm{C}$ & $180 \mathrm{~min}$ & 16 & 08 & 09 & 07 \\
\hline $60^{\circ} \mathrm{C}$ & $360 \mathrm{~min}$ & 30 & 21 & 18 & 12 \\
\hline $60{ }^{\circ} \mathrm{C}$ & $720 \mathrm{~min}$ & 20 & 14 & 12 & 08 \\
\hline $80^{\circ} \mathrm{C}$ & $30 \mathrm{~min}$ & 40 & 20 & 20 & 20 \\
\hline $80^{\circ} \mathrm{C}$ & $60 \mathrm{~min}$ & 75 & 48 & 58 & 17 \\
\hline $80^{\circ} \mathrm{C}$ & $180 \mathrm{~min}$ & 36 & 20 & 20 & 16 \\
\hline $80^{\circ} \mathrm{C}$ & $360 \mathrm{~min}$ & 84 & 70 & 56 & 18 \\
\hline $80^{\circ} \mathrm{C}$ & $720 \mathrm{~min}$ & 34 & 15 & 18 & 16 \\
\hline $100{ }^{\circ} \mathrm{C}$ & $30 \mathrm{~min}$ & 11 & 04 & 06 & 05 \\
\hline $100^{\circ} \mathrm{C}$ & $60 \mathrm{~min}$ & 10 & 03 & 03 & 07 \\
\hline $100^{\circ} \mathrm{C}$ & $180 \mathrm{~min}$ & 13 & 06 & 34 & 09 \\
\hline $100^{\circ} \mathrm{C}$ & $360 \mathrm{~min}$ & 55 & 18 & 30 & 25 \\
\hline $100{ }^{\circ} \mathrm{C}$ & $720 \mathrm{~min}$ & 48 & 25 & 18 & 30 \\
\hline Control & & 14 & 08 & 05 & 09 \\
\hline
\end{tabular}

* Values are means of five replicates. \% Germ, percentage germination; Germ En., germination energy; HV, high vigour (above mean); $\mathrm{LV}$, low vigour (below mean). Experimental mean height, $6.45 \mathrm{~cm}$ after 30 days. 
associated with an F-Ratio 32.14 (2.04 table value), suggesting treatments difference at $5 \%$ level of significance. Comparison of mean height was performed using the Least Significance Difference (LSD) multiple range test (table II and $I V$ ). The comparison of pre-treatments mean height show that heating seeds at $80^{\circ} \mathrm{C}$ for 360 and 720 min and at $100{ }^{\circ} \mathrm{C}$ for 30 and $360 \mathrm{~min}$, produced seedlings of a higher vigour than the other heat pre-treatments. Similarly, boiling $\left(100^{\circ} \mathrm{C}\right)$ gave greater vigour growth for seedlings raised from the 10 and 40 s pre-treated seeds. Significant differences in seedling height were observed for the pretreatments under the various temperature ranges and exposure time (table $I I$ and $I V$ ).

Table II. Comparison of treatment mean height for $D$. cinerea seedlings raised from oven-heat pre-treated seeds.

\begin{tabular}{lcc}
\hline Pre-treatment & Ranked mean & LSD $(\mathrm{H})+$ mean \\
\hline Control & $5.80 \mathrm{a}$ & 6.89 \\
$40^{\circ} \mathrm{C} 720 \mathrm{~min}$ & $6.50 \mathrm{ab}$ & 7.59 \\
$40^{\circ} \mathrm{C} 30 \mathrm{~min}$ & $6.70 \mathrm{ab}$ & 7.79 \\
$100^{\circ} \mathrm{C} 60 \mathrm{~min}$ & $7.00 \mathrm{bc}$ & 8.09 \\
$100^{\circ} \mathrm{C} 180 \mathrm{~min}$ & $7.10 \mathrm{bc}$ & 8.19 \\
$100^{\circ} \mathrm{C} 720 \mathrm{~min}$ & $7.10 \mathrm{bc}$ & 8.19 \\
$60^{\circ} \mathrm{C} 30 \mathrm{~min}$ & $7.20 \mathrm{bc}$ & 8.19 \\
$40^{\circ} \mathrm{C} 360 \mathrm{~min}$ & $7.50 \mathrm{bc}$ & 8.29 \\
$40^{\circ} \mathrm{C} 180 \mathrm{~min}$ & $7.80 \mathrm{~cd}$ & 8.59 \\
$60^{\circ} \mathrm{C} 180 \mathrm{~min}$ & $8.37 \mathrm{de}$ & 9.46 \\
$40^{\circ} \mathrm{C} 60 \mathrm{~min}$ & $8.40 \mathrm{de}$ & 9.49 \\
$60^{\circ} \mathrm{C} 60 \mathrm{~min}$ & $8.40 \mathrm{de}$ & 9.49 \\
$60^{\circ} \mathrm{C} 720 \mathrm{~min}$ & $8.50 \mathrm{de}$ & 9.69 \\
$80^{\circ} \mathrm{C} 180 \mathrm{~min}$ & $8.60 \mathrm{de}$ & 9.89 \\
$60^{\circ} \mathrm{C} 360 \mathrm{~min}$ & $8.80 \mathrm{de}$ & 9.99 \\
$80^{\circ} \mathrm{C} 30 \mathrm{~min}$ & $8.90 \mathrm{e}$ & 9.99 \\
$80^{\circ} \mathrm{C} 720 \mathrm{~min}$ & $8.90 \mathrm{e}$ & 9.99 \\
$100^{\circ} \mathrm{C} 30 \mathrm{~min}$ & $9.00 \mathrm{f}$ & - \\
$100^{\circ} \mathrm{C} 360 \mathrm{~min}$ & $9.10 \mathrm{f}$ & - \\
$80^{\circ} \mathrm{C} 60 \mathrm{~min}$ & $9.20 \mathrm{f}$ & - \\
$80^{\circ} \mathrm{C} 360 \mathrm{~min}$ & $9.40 \mathrm{f}$ & -
\end{tabular}

** Mean followed by the same letter are not significantly different at $5 \%(\mathrm{LSD}=1.09)$. Multiple range test $(\mathrm{F}-$ ratio $=33.14)$.

\section{Discussion}

Dormancy in Dichrostachys cinerea, may be due primarily to the impermeability of the waxy seed coat to water and gases, as well as the presence of inhibiting substances which work concurrently with the former to suppress germination to the low level observed under natural conditions, even though the inhibitory substances might not be hormonal in nature [11]. This implies that to overcome dormancy and improve germination in $D$. cinerea seeds, pre-treatments that are severe enough to breakdown the seed coat barrier as well as destroy or dislodge the inhibitory substances will be required.

Seeds differ in their response to heat treatment. The precise sensitivity differs with species resistance to high or low temperature, and principally linked to the duration of exposure. During the present study, oven-heat pre-treatment at $80^{\circ} \mathrm{C}$ recorded the highest results for the dry-heat pretreatment. At $80{ }^{\circ} \mathrm{C}, 360 \mathrm{~min}$ of treatment gave $84 \%$ germination and germination energy of $75 \%$ low germination percentages were observed for lower temperature $\left(40\right.$ and $60^{\circ} \mathrm{C}$ ) and for higher temperature $\left(100{ }^{\circ} \mathrm{C}\right)$. While poor germination in the former $\left(40\right.$ and $60{ }^{\circ} \mathrm{C}$ ) may be due to the less severity of the temperature ranges to crack the seed coat, protein denature at high temperature may account for the low germination recorded for the latter $\left(100{ }^{\circ} \mathrm{C}\right)$. High germination percentages observed for the $80^{\circ} \mathrm{C}$ range may be due to the effective disintegration of the seed coat, thereby allowing entry of water and gases and is an indication that the temperature range of $80^{\circ} \mathrm{C}$ is probably closer to the seed optimal germination temperature. This view is also shared by others [11]. Similarly, high percentages were obtained for Parkia clappertoniana and Bixa orellana seeds, respectively $[3,8]$.

Seed coat barrier breakdown by rapture of the lens tissue [2], or by raising and splitting of the hard coat, creating a passage for entry of water into the seed interior, may have been responsible for the high germination percentages recorded for boiling water pre-treatment for 10 and $40 \mathrm{~s}$. However, pro- 
long immersion, which leads to protein denature and seed death due to oxygen scarcity, a condition commonly associated with water at high temperature, probably accounts for the progressively lower germination percentages observed with increased exposure time for boiling pre-treatments (table III). Data from other reports $[1,7,9]$ support this view. High germination energies were also recorded for $10 \mathrm{~s}(85 \%)$ and $40 \mathrm{~s}(65 \%)$ pre-treatments. The pre-treatments with high energies for the oven-heat and boiling (tables $I$ and $I I I$ ) can be applied in nursery settings to produce uniform planting stock, with a good nursery recovery of high quality seedlings. Poor nursery recovery of seedlings of low planting value will result from the pre-treatments of low germination energies, as they produced seedlings of vary sizes [12]. Of interest is the observation that the control treatments in both cases (oven-heat and boiling) recorded one of the lowest percentage germination and germination energy, and produced seedlings of the lowest mean height. This suggests an initial poor germination energy of the untreated seeds, indicating that the seeds require scarification or other pre-treatments before better seedling performance can be achieved. In conclusion, it is evident that boiling $\left(100{ }^{\circ} \mathrm{C}\right)$ and oven-heat treatment had variable effect on germination and vigour of seedling growth on $D$. cinerea. Boiling water $\left(100^{\circ} \mathrm{C}\right)$ treat-

Table III. Germination $\%$ after 30 days, germination energies after eight days period and vigour categories based on germination height after 30 days for Boiling $\left(100{ }^{\circ} \mathrm{C}\right)$ Pre-treatment.

\begin{tabular}{lcccc}
\hline Pre-treatment & \%Germ. & Germ. En. & HV & LV \\
\hline Boiling 10 s & 94 & 85 & 70 & 24 \\
Boiling 40 s & 88 & 65 & 58 & 30 \\
Boiling 60 s & 50 & 35 & 28 & 22 \\
Boiling 300 s & 03 & 20 & 18 & 12 \\
Boiling 900 s & 05 & 02 & 01 & 04 \\
Control & 11 & 07 & 89 & 07 \\
\hline
\end{tabular}

* Values are means of five replicates. \% Germ, germination energy; HV, high vigour (above mean); experimental mean height -6.45 after 30 days. LV - low vigour (below mean).
Table IV. Comparison of treatment mean height for $D$. cinerea Seedlings raised from boiling $\left(100^{\circ} \mathrm{C}\right)$ Pre-treated.

\begin{tabular}{lcc}
\hline Pre-treatment & Ranked mean* & LSD(H)+mean \\
\hline Control & $5.70 \mathrm{a}$ & 7.43 \\
Boiling 900 s & $6.50 \mathrm{ab}$ & 8.23 \\
Boiling 300 s & $7.80 \mathrm{bc}$ & 9.53 \\
Boiling 60 s & $8.05 \mathrm{bc}$ & 9.78 \\
Boiling 40 s & $8.80 \mathrm{~d}$ & - \\
Boiling 10 s & $9.40 \mathrm{~d}$ & - \\
\hline
\end{tabular}

* Mean followed by the same letter are not significantly different at $5 \%$ (LSD 1.73). Multiple range rest $(\mathrm{F}-$ Ratio $=22.36)$.

ment for 10-40 s was the most effective and hence present the most ideal pre-treatment for germinating $D$. cinerea seeds and raising high quality seedlings with maximum nursery recovery.

\section{References}

[1] Anoliefo, G.O., Gill L.S. Seed germination of Peltophorum inerme (Roxb). ilonos (Leguminosae), Int. J. Trop Agric. (1992) 246-253.

[2] Cavanagh T., Germination of hard seeded species (order Fabales), in: Lagkamp F. (Ed.), Germination of Australian Native Plant seeds, Inkaka Press, Melbourne Australia, 1987, pp. 58-90.

[3] Etejere E.O., Fawole M.O., Sani A. Studies on the seed germination of Parkia clappertoniana, Turrialba 32 (1981) 181-185.

[4] Gill L.S., Bamidele J.F. Seed morphology, germination and cytology of three Savanna tress of Nigeria, Nigerian J. For. 2 (1981) 16-23.

[5] Gill L.S., Hussaini S.W.H., Musa A.H. Germination seedling and cytology of Delonix regia, Legume Res. 4 (1982) 51-55.

[6] Gill, L.S., Jegede, E.O., Hussaini, Studies on the seed germination of Acacia fernesiana (L.) Wild (Leguminosae), J. Tree Seed Sci. 5 (1986) 92-97.

[7] Gunn B.V., Germination pre-treatments of selected Acacia species from the Pilbara region of Western Australia, in: Turnbull J.W. (Ed.), Tropical Tree Seed Research Canberra, Australia, 1990, pp. 46-50. 
[8] Idu M., Seed germination in Bixa orellana (L.) J. Trop. Agric. 32 (1994) 17-21.

[9] Idu M., Seed development and germination responses of two Cassia L. species. Org. Int. Environ. 2 (1995) 65-68.

[10] Keay R.W.T., Trees of Nigeria, Oxford Science, London, 1989.

[11] Kelly K.M., Van Staden J., Bell W.E. Seed-coat and dormancy, Plant Growth Regulation 11 (1992) 201-209.
[12] Marunda C.T., Effects of Seed pre-treatments on development of Acacia agriculformis and A. holosercea Seedlings, in: Tumbull J.W. (Ed.), Tropical Tree, Seed Research ACIAR, Canberra, Australia, 1990, pp. 33-36.

[13] Mayer A.M., Poljakoff-Mayber A., The Germination of Seeds, Pergamon Press. London, 1989, pp. 71-84.

[14] Seward B.R.T., The production, handling testing of forest trees in Zimbabwe a review of methods and results, Zimbabwe Bull. For. Res. (1980) 8-19. 